\title{
EVOLUTION AND MATERIAL CULTURE
}

Jan Apel \& Kim Darmark
In this paper the authors argue that the renewed interest in cultural evolution in archaeology may have a fundamental effect on the taxonomies employed and the role of archaeology as a discipline.

Key words: cultural evolution, material culture, archaeological theory, selection, cultural transmission, taxonom

\section{INTRODUCTION}

We decided to write this paper after receiving an invitation from the editors of Current Swedish Archaeology, who expressed a wish to include debates on contemporary issues in archaeological theory. The time is ripe to start a Scandinavian debate on evolutionary issues and archaeology, not least since the year 2009 is the bicentennial of the birth of Darwin as well as the I 5 oth anniversary of the publication of On the Origin of Species. Although we are positive toward the renewed interest in empirical matters among the new generation of archaeologists, we feel that it is important to maintain vital theoretical discussions. We hope that the following text will spark a debate on the theory, methods and goals of material culture studies.

Evolutionary theory has been discussed in American archaeology for a long time and is gaining ground in European archaeology as well, especially in Britain. Recent archaeological conferences include sessions devoted to the subject, and at Stockholm University the Centre for the Study of Cultural Evolution has been active since 2007 .

The debate on these issues has, as yet, not penetrated Scandinavian mainstream theory in a substantial way (for exceptions, see Persson 
I999; Kristiansen 2004; Riede 2005; Apel \& Darmark 2007). The theoretical climate in Scandinavian archaeology during the last 20 years has been characterized by a contextual and critical approach that has resulted in a fragmented, narrative, anti-scientific archaeology of marginal interest to other disciplines. In our view an alternative theoretical framework needs to be presented and discussed. The use of evolutionary theory in archaeology and the social sciences is heavily laden with historical baggage which acts as an obstacle for the acceptance of its basic ideas among social scientists. However, much of the scepticism can be accounted for by vague notions about what modern evolutionary thinking actually includes. This paper is an attempt to (I) present what we believe to be the fundaments of evolutionary theory, (2) to present how studies of material culture can be related to evolutionary theory, and (3) to discuss what the advantages of such an evolutionary viewpoint in social studies might be.

Critics have pointed out that the use of a biological vocabulary in studies of cultural phenomena, including such terms as "variation", "selection" and "drift", has a metaphoric value only, and that there are no methods to scientifically secure the connection between empirical reality and evolution theory (Fracchia \& Lewontin I999; Bamforth 2003; Gabora 2006). In the current archaeological debate, a contrast is often made between agency perspectives, which stress individual choices and particularistic historicism, and evolutionary and Darwinian explanations (see Kristiansen 2004). However, as we see it the theory of cultural evolution is a unifying theoretical framework that not only brings together archaeologists working on different levels of explanation, but also researchers from other disciplines (Mesoudi et al. 2006). We do not agree that evolutionary theory is a matter of doing traditional archaeology with fashionable and scientific metaphors, but that evolutionary perspectives may have a fundamental effect on the questions asked, the taxonomies employed, and the role of archaeology as a discipline. We agree with Runciman (2005) that the goal of archaeologists working within an evolutionary paradigm is to explain how and why certain cultural traits (a certain kind of pot or flint tool, funeral rite or custom) are selected and thereby become more common than other competing traits over time. In this context it is important to stress that the selection of cultural variants among humans in no way is restricted to an adaptation to natural environments. Even if adaptation might be expected in the long run, studies of individual 
choices and historical events in prehistory are needed because they are important parts of evolutionary history. This is true since humans are actively creating and modifying the social and physical environments to which they have to adapt. Thus, in relation to other animal species with socially transmitted culture, humans are active niche constructors (Laland \& Brown 2006; Iriki \& Sakura 2008).

The realisation that Darwinism and action theory exist on different levels is the starting-point for a joining of the two. Evolution theories work on a deeper and more general level of explanation than the discourses of action theory conducted within archaeology (Cullen 2000:2f; Riede 2005). They contribute basic knowledge concerning certain mechanisms which are fundamental to history and which can be used to put individual historical events and trends in the course of history into a larger picture. In order to do so, close study of individual historical events or processes is required (Shennan 2000:340). Therefore, there is no opposition between these two perspectives; they simply operate on different temporalities and consequently answer different kinds of questions, and both levels are needed to create an interesting and relevant archaeology.

\section{A BRIEF HISTORY OF EVOLUTIONARY THEORY IN CULTURAL RESEARCH}

The use of evolutionary concepts in the social sciences predates Darwin. The colonialism of the I8th and I 9 th centuries brought Western researchers into close contact with populations living under radically different conditions regarding subsistence, technology and social organization. Empirical observations made by anthropologists from different corners of the world became the foundation upon which to build a frame of reference with an evolutionary touch. The archaic societies encountered were seen as representing different steps on an evolutionary ladder, ranging from simple, low-tech societies to advanced, complex high-tech civilizations. An increasing level of complexity was seen as intrinsic to cultural evolution and different classificatory schemes were proposed, Morgan's unilinear social evolution (band-tribe-chiefdom-state) being a well-known example since it inspired Engels and Marx and thus radically affected the course of 2oth-century history. These schemes were united by a teleological notion where evolution was seen as having a definite goal. Not surprisingly, this view was combined with value judgments. Advanced societies (closer to the ul- 
timate goal) were seen as "better" than primitive societies since these had stagnated on their path to their predestined future. Thus, cultural evolution fitted nicely into the grand colonial project; the enlightened Western states needed no further excuses to bestow their civilisatory blessings on their less developed neighbours. The I 9 th-century school of cultural evolution was an attempt to generalize the empirical record inductively in order to make sense of the substantial differences between the peoples of a shrinking world. This scientific desire might have been combined with political ambitions. It is clear that the point of departure was not a coherent theoretical evolutionary framework, and even after Darwin's publication of On the Origin of Species the I 9 th- and early 20 th-century cultural evolutionists maintained a thoroughly non-Darwinian notion of evolution (Bettinger I99I).

In contrast, a materialistic or instrumental perspective is characteristic of the natural sciences. This perspective works on the supposition that any division of natural or cultural phenomena into types or categories is defined by the scientist in his/her own time and does not necessarily coincide with real, historical categories. As opposed to this way of thinking, I9th-century social evolutionist theories worked on the supposition that the task of the researcher was to discover, in his/ her work, essential categories in the source material. Perhaps the most obvious scientific example of a change from essentialism to materialism is the introduction of Darwin's theory of evolution in biology during the Igth century. Prior to Darwin, biologists, such as Linnaeus, tended to look upon different species as static, essential categories, which the biologist was supposed to discover and chart. Darwin's emphasis on biological development as a continuous process, where, even within particular species, there is an individual variation constituting the prerequisite for the development of new species, caused a fundamental theoretical change from essentialism to materialism. This in turn changed our view of ourselves, our origin and nature.

The social and political consequences of early cultural evolutionary thinking, such as eugenics and other atrocities, understandably promoted a reaction and social sciences turned to a thoroughly antibiological stance: the Standard Social Science Model (Tooby \& Cosmides I 997). According to this point of view, there are limited, if any, biological constraints on human behaviour. Instead human behaviour has been regarded as exclusively formed by processes of socialization as well as relativization of culture. Within the Standard Social Science 
Model, culture is selected by free agents making active, unconstrained choices, and there has been a tendency to stress the vast plethora of different cultural practices rather than to look for cultural universals (Workman \& Reader 2004). The archaeological counterpart to the model has its roots in Boasian anthropology as well as Collingwood's historicism and is to be found within the different strands of postprocessualism.

Beginning with the works of authors such as E.O. Wilson, W. Hamilton and R. Dawkins, the socio-biological school of thought was formalised during the late 1970 s and early 80 . This constituted a return to biological, reductionist explanations of human behaviour based on Darwinian evolutionary theory. Accordingly, human behaviour, including many cultural manifestations, was regarded largely as a result of genetic inheritance of adaptive variants. Even if it was acknowledged that culture occasionally drifts away from a fitness-maximizing optimum, behaviours that in the long run had important effects on Darwinian fitness would tend to be adaptive (Boyd \& Richerson 1987:65).

This mode of thinking is usually carried out by researchers outside the social sciences and often includes a view of culture that is overly simplified and unattractive to social scientists. However, the intrusion of "outsiders" into the realm of culture and the impact of their reasoning on popular thought is to be attributed entirely to the pervasive contextualism and unwillingness on behalf of social science to tackle fundamental issues, such as striking cross-cultural similarities between seemingly unrelated groups of people (Bloch 2003). The growing realisation among biologists that many animal species possess socially inherited cultural behaviours has resulted in an interest in the cultural behaviour among humans as well. Cavalli-Sforza (I 986) published an early sketch of the relationship between cultural and biological evolution, in which he pointed out many analogies as well as differences. Whereas biological evolution relies on the introduction of genetic variation through such processes as mutation, variants which can subsequently be propagated through genetic parent-to-child transmission, cultural traits - ideas, beliefs, languages etc. - are transmitted in more complex ways, and new variants are also introduced in more complex ways, innovation being the more obvious. "The study of culture in humans and animals has only now begun" (Cavalli-Sforza I 986:855), is a quote that clearly expresses the disregard which the population geneticist has had for cultural studies conducted by social scientists for 
centuries, a disregard which cannot be attributed to personal arrogance alone. Indeed, the adoption of the Standard Social Science Model of culture, with its emphasis on the contextual importance of thick descriptions and cultural relativism and its denial of scientific reductionism, seems to have resulted in the marginalisation of cultural research in general.

Theories on human culture have in other words been highly dichotomized and divided into seemingly incompatible camps. It is obvious to us that biology is not everything and that culture has played a great role for humans in an adaptive sense. However, culture has not liberated human beings from their biological constraints. The remarkable adaptability of humans can not just be attributed to some great genetic variation from which favourable qualities have been selected according to the principle of natural selection. Instead, this adaptation has taken place mainly as a result of the ability to make use of material culture. By making warm clothes and creating flexible hunting techniques, as well as a logistic organization which included the storage of food, the knowledge of fire and preparation of hides, a typically tropical species succeeded in adapting to temperate climate zones, and in some cases even to arctic conditions (Gräslund I98I). Consequently, on a fundamental level, material culture can be seen as an expression of man's non-physical adaptation to his surroundings (White 1959:3) and must be incorporated into any theory of human evolution.

Dual inheritance theory as proposed by Boyd \& Richerson (1985) and modern cultural evolution is an attempt at finding a common middle ground between these camps. Dual inheritance is the idea that, even though the human capacity for culture is evolved and has biological roots, cultural evolution develops its own rules and is an inheritance system independent of genetic inheritance. Of importance is that culture is defined as an inheritance system where different cultural variants are selectively transmitted both within and across generations, which means that the components necessary for Darwinian principles to act are present.

\section{MODERN EVOLUTIONARY THEORY AND MATERIAL CULTURE STUDIES}

Biological evolution can be summarized as descent with modification. Genes are inherited through generations, and mutations create diversity which, through natural selection, adjusts species to the environ- 
ment in which they live. Darwin's theory of natural selection is characterised by three features: (I) information is passed on from parent to child, (2) the individuals in a population are not identical, and (3) there is a connection between the hereditary traits (phenotype) of an individual and his/her ability to survive and reproduce (See Fagerström 1994). An important distinction between the Darwinian theory of evolution and other evolutionary theories (Early Cultural Evolution and Lamarckian evolution) is that Darwinian evolution is not teleological; it has no ultimate goal.

It has been pointed out that biological evolution may be just one of several special cases of a more general evolutionary theory (Campbell I974; Runciman 2005:3) and according to this idea evolution is not constricted to living organisms. The evolution of any phenomenon can from this point of view be regarded as a temporal change in an ensemble of elements. The individual elements in the ensemble can be physical objects like organisms or different elements of artefacts or properties like size or chemical composition or syntactic structure (Fracchia \& Lewontin 1999:60). Whether or not we are talking about physical objects or attributes of artefacts (or packages of technologies and behaviours), it is not any one individual element but the composition of the ensembles that is at the centre of interest. A gradual change in the frequency of elements over time within a defined ensemble (a technology, an artefact type) constitutes an evolutionary process. Accordingly, the notion that temporal changes in material culture may be the result of a process of descent with modification is hardly controversial for any archaeologist who recognizes the variation of material culture in time and space (Wenke 1989:32). Consider, for instance, the variety of relative chronologies that have been designed by archaeologists to capture how different artefact traditions evolve over time. The findcombination method and the different seriation methods in archaeology were specifically constructed to demonstrate changes over time in the compositions of elements, for instance stylistic elements of pottery (Gräslund I974).

However, it has been realised that many of the traditional typological taxonomies are not well suited to study temporal change from the perspective of descent with modification, since they tend to mask variation between individual artefacts instead of revealing variation. Thus, many of the traditional typologies used in archaeology are essential in that they are considered intrinsic categories discovered by the archae- 
ologist (Lyman, O’Brien \& Dunnell 1997). While we believe that the question of essentialism and culture might have to be explored further in future research, we agree that typologies based on essential categories are problematic for many reasons. Morphometric taxonomies are better suited to shed light on continuous variations, especially when they are used on artefact categories such as metal objects and pottery where formal properties are established in the production and maintained through the life cycle of the artefact. However, regarding certain categories of finds, such as flaked and carved tools, they may be problematic due to the subtractive nature of stone and bone industries (Apel \& Darmark 2009). A major challenge in archaeology is to rework our taxonomies so that they take variation into account; by doing so we can utilize powerful statistical methods developed in biology, such as cladistics, which is used to analyze how different taxa (e.g. in biology, species; in culture, artefacts) relate to each other in evolutionary time. This work has begun (see Lipo et al. 2006; Mace et al. 2005; Shennan 2009) but much work, including experimental work, remains to be done. The typological work within an evolutionary framework should be focused on revealing historical relationships among different artefact forms and not, as with many of the traditional typologies, mere chronological relationships. This was understood already to a certain degree by Montelius in the late I 9 th century (Riede 2006), even though his theoretical intentions were downplayed in later research (Gräslund I974; Riede 2006).

While the notion of descent with modification has been at the core of the typological research of archaeologists since the I 9 th century, we will now see whether evolutionary terms such as "variation", "selection" and "heredity" are applicable to culture as well, which would imply that culture is a suitable subject for a Darwinian analysis.

\section{INHERITANCE}

In contrast to the transmission mechanisms of biological evolution which basically is vertical transmission of genes between parents and children, the mechanisms of the transmission of cultural knowledge are more complex (Cavalli-Sforza 1986). Cultural information can be transmitted vertically between the generations from older relatives to children, horizontally between unrelated individuals, from one person to many by teaching, or from many to one by peer pressure. An important distinction is also that an individual can observe behaviours 
of peers around him and choose among them (Boyd \& Richerson I987:65). An ability to imitate behaviour, probably related to a good understanding of the intentions of our conspecifics, separates humans from other species. Human cumulative cultural reproduction is dependent not only on the ability to emulate or imitate behaviour but also on inherent pedagogical resources that enable humans to make long-term educational investments in their children (Tehrani \& Riede 2008).

\section{VARIATION AND CULTURAL TRANSMISSION}

Cultural variation may occur randomly (Boyd \& Richerson 1985 ). Cultural information will be passed on from individual to individual and undergo changes due to bad memory, misconceptions etc. This means that there is an analogy to biological mutations in cultural transmission. The degree to which cultural information is subject to random changes of this kind is affected by social factors such as the content, context and mode of transmission (Eerkens \& Lipo 2007). For example, repeated instructions on a simple issue from a respected person versus an overheard conversation in a noisy setting will have very different outcomes regarding the probability of random errors. As a consequence, random variation occurs over time when, for example, a craft tradition is passed down through generations. This variation will eventually form the basis of selection. Variation will also appear through cultural drift. In small populations, random variation may cause some cultural technical elements to be forgotten and may change the frequency of other features. For instance, picture a small group of people moving to a remote island for some reason, and losing contact with the mother population. The cultural knowledge of these pioneers will only be a sample of the knowledge in the original population and there is also a chance that this sample is biased: it is not representative of the average cultural skills. Depending on the scenario, over time it is likely that their craft will show marked differences from the mother craft, due to cultural drift. This is not a new thought in archaeology. It is likely that such ideas, more or less implicitly, have been behind many cultural-historical interpretations of archaeological materials. For example, it is plausible that a craft tradition shared by a large geographical area - such as the making of a certain kind of flint projectile point - will eventually, due to an increase in population or changed rules of marriage resulting in a loss of contact between the groups, produce regional or local varieties of points with a common origin in an older tradition. 
Both random variation and drift are biological concepts. Many opponents of evolutionary approaches to studies of culture have argued that human inventiveness, because it lacks a counterpart in biological evolutionary theory, makes evolutionary approaches superfluous in cultural research. Central to Darwinian evolution is the insight that the creation of variants is a process that is independent of their selection, which intuitively seems to be very different from what is the case with culture. Major criticisms of the idea of a Darwinian cultural evolution stem from this dichotomy between blind and random biological evolution and a purposeful, non-random, cultural evolution. If man can accurately foresee future conditions he will be able to modify his behaviour in order to adapt to these conditions, in which case a Darwinian perspective would be superfluous. However, as Mesoudi (2008) points out, the presence of human foresight is not to be confused with clairvoyance. Even though the human brain is an effective simulator of future events, and we are able to use our imagination to obtain educated guesses concerning the future, it remains just that - guesswork. Studies on the history of innovations also clearly show that our notion of the heroic inventor, who perceives a need and then designs a solution, is flawed and romanticized. Rather, scientific breakthroughs often are the result of considerable trial and error, often random and conducted by several people. Mesoudi also discusses what he calls biological foresight. Under stressful conditions bacteria will produce an enzyme that increases mutation rates, potentially leading to the rise of beneficial genetic variants and an adaptation to the changing environment. Such behaviour has its counterpart in human technological adaptation, for example to arctic climates (Fitzhugh 200I). It is furthermore obvious that human decision making is not as goal oriented as we might tend to believe.

Individual learning combined with cultural transmission results in what Boyd and Richerson call a Lamarckian effect. Kronfeldner (2007) distinguishes between variational (Darwinian) and transformational evolution (Lamarckian). In transformational evolution variation is not required, but is rather a disturbance. Instead, transformational evolution is propelled by inherent forces striving towards increasing complexity and adaptation. She suggests that these evolutionary models need not be mutually exclusive. Even though culture includes elements of guided variation (i.e. directed against anticipated circumstances) this variation can be regarded as only one of the sources of variation 
in the population; Darwinian principles will still act to sort the variation through selective mechanisms.

\section{SELECTION AND ADAPTATION}

So, variation is created in culture in different ways. Not all variants have the same fitness or, in the words of Leonard and Jones ( 1987 ), replicative success. There are different sorting processes that act to increase the frequencies of certain cultural traits and sort out others.

Selection in biology is usually attributed to environmental forces. Had the dodo been exposed to predators in its natural environment it would not have been such an easy prey for the I 7 th-century sailors responsible for its extinction. Regarding human evolution, it is necessary to take account of the fact that human selective environment is not only a matter of the physical environment; the social environment is a major factor as well. This applies to the evolution of biological traits as well as cultural traits. For example, the existence of altruistic behaviour among humans, the fact that we are nice to our fellow man without consciously calculating on receiving rewards, could be explained by the impact of our past social environment. In the past, most people lived in small-scale societies in which the maintenance of a good reputation was of essence, in order not to be ostracized and also in order to keep reaping the benefits of cooperative enterprise with one's conspecifics. Even though our social circumstances are radically different today, we still maintain the instincts imprinted in us (Gärdenfors 2006:37ff). If social environment affects our genetic composition in this way, it is not surprising that it will also influence the selective mechanisms in cultural evolution.

Often we employ rather rough heuristic devices, rules of thumb, in order to choose between different behavioural variants. Boyd \& Richerson (1985) presents a summary of some common rules of thumb that, though rational in the face of the risky process of individual learning, can be significantly flawed in relation to the adaptive circumstances. In short, our choice of cultural role models is based on how common they are in our social environment, on how close they are to us or how we perceive their overall success, rather than on detailed and accurate analysis of the behaviour of the models in relation to our perception of present or anticipated environmental circumstances. In conclusion, the seemingly purposeful and planned behaviour of man does not award him a position beyond the grasp of Darwinian processes. 
The aim of the following example is to try to clarify the role of selection of material culture traits in a prehistoric context. In southern Scandinavia, the Middle Neolithic is characterised by the Pitted Ware culture, which seems to be a period of temporary return to hunting and gathering subsistence. This transition is marked by changes in material culture, for example the appearance of various types of tanged arrowheads made of blades from cylindrical cores. These were examined by Becker (I950) and organized into a chronological scheme. The evolutionary scheme is characterised by changes in the use of secondary treatment of the blades. During the early phases the blades are subjected to very minimal secondary treatment: rudimentary retouching of the tip and the base in order to create the outline and the tang of the tool. The later projectiles are made from crested blades with a triangular cross-section, displaying surface covering flaking on all three faces, and there also seem to be intermediate forms made from regular blades but with an increase in the use of secondary treatment, i.e. large portions of the two faces have been pressure flaked. Is this only a case of Becker being influenced by an evolutionary model in his sequencing of the arrowheads? Possibly, but intriguingly enough this pattern of change in lithic projectile point manufacture has interesting parallels elsewhere. In central Russia, the earliest pottery appears around $6000 \mathrm{Cal}$. BC and the style has been termed the Upper Volga Neolithic. Similar pottery was manufactured in the region for about a thousand years and then replaced around $5000 \mathrm{Cal}$. BC by CombPit Ware pottery. The Upper Volga Neolithic is divided into three welldated phases, which are described by Engovatova (I998). The projectiles of the earliest phase show considerable continuity with the preceding Mesolithic (Butovo) traditions and are produced from blades using short retouching of the perimeter. The following phase is characterized by a decrease in blade production and an increase in the degree of secondary modification of the tools, which frequently display surface covering flaking on one side. These two trends continue in the third phase, when blades are very rare, and projectile points are made by bifacial, surface covering flaking, a trait which is ubiquitous within the later Comb-Pit Ware Neolithic. This transition is empirically best known in the Upper Volga region, but similar changes seem to characterize many parts of Northern Eurasia (Darmark, in press), and other examples have been pointed out. The well known Solutrean bifacial laurel leaf points seem to have an evolutionary history of gradual de- 
velopment and a combination of elements with roots in both the Eastern Gravettian and the North African Aterian (Tiffagom 2006), and a similar line of development characterizes the changes within the Big Arrowheads Industry in the Anatolia and the Levant (Gopher I999; Koslowski I 999). This evolutionary convergence (Fig. I), where similar traits are gradually selected in clearly unrelated contexts, strongly suggests a common denominator, the nature of which is still uncertain. Should it be attributed to an increase in efficiency, or to changes in raw material procurement, or perhaps to human cognitive predispositions? Whatever the mechanisms underlying this phenomenon, we think that this is an example of the kinds of questions an evolutionary archaeology could pose and where a degree of reductionism is fruitful in order to enlighten similarities rather than differences.

Biased transmission also affects the variation of cultural traits in human population. This evolutionary force occurs as a consequence of the ability of cultural transmission to favour certain cultural varieties over others. One illustration of biased transmission is that people, as psychological data show, tend to adopt the same view or make the same choices as the majority does, even though it goes against their own experience. As a result, the frequencies of the most common cultural expressions tend to increase over time. It has, for instance, been dem-

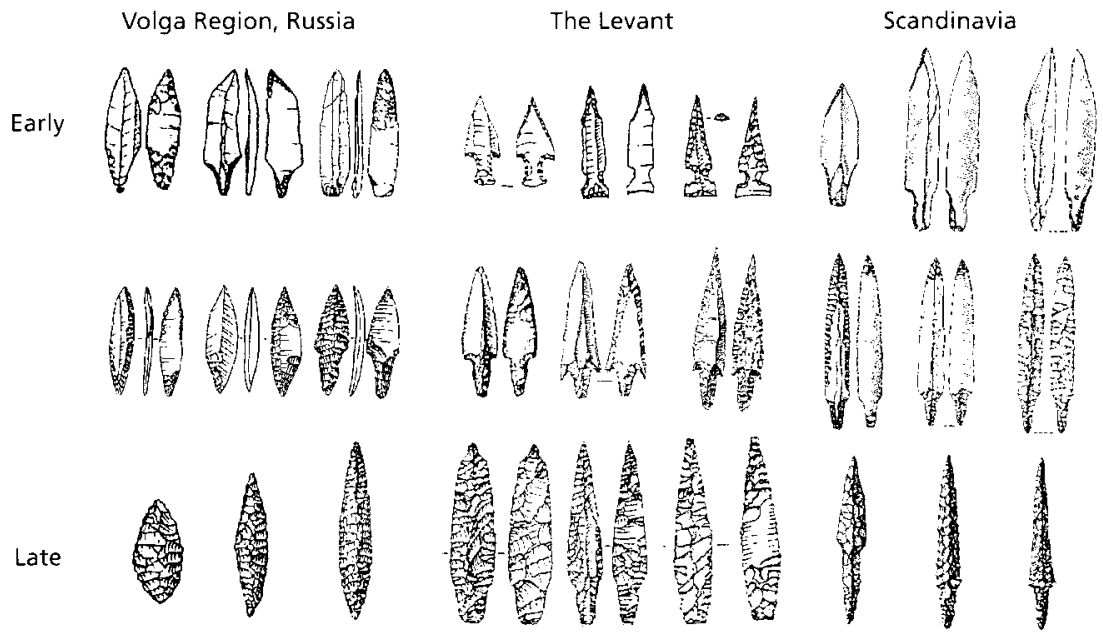

Fig. 1. A comparison between arrowhead industries in the Volga region in Russia, the Levant and Scandinavia, illustrating a convergence in the development towards an increased use of secondary flaking of the surface. The industries are not contemporaneous and the artefacts are not presented in scale. The drawings are selected from Vang Petersen 1999, Gopher 1999, Kol'tsov 1.989 and Oshibkina 1996. 
onstrated that the relative success of pop songs in charts is a result of people copying each other rather than making a personal evaluation of the qualities of each song (Bentley 2007). In other words, people tend to vote for the song with the most votes. A similar pattern can probably be discerned with regard to the use of references in scientific papers. The reason certain papers are more referenced than others can, at least in some cases, be that they happen to be included in the references of a very influential paper and therefore are copied in other papers.

\section{CONCLUSION}

Evolutionary approaches in archaeology focus on long-term stability and change in the archaeological record. Contextual information is vital in this undertaking but not in order to argue for the uniqueness of the cultural context. By focusing on comparable traits, long-term historical relationships may be uncovered.

Evolutionary approaches in archaeology, which consciously apply powerful statistical methods such as cladistics to describe change in material culture through time and space, also stand a chance of contributing important information on contacts between cultures and areas where no significant gene flow can be discerned with genetic methods. While interesting genetic studies on the distribution of domestic animals, beginning with the dog in the late Pleistocene-early Holocene (Savolainen et al. 2002, Malmström et al. 2008), seem to indicate farreaching networks of a surprisingly early age between peoples without close biological contacts, such research would be greatly improved by similar studies of traditions of material culture.

We also believe that an evolutionary perspective on humans and their cultural expressions will rest on a view of humans as both cultural and biological beings. As a consequence of this, researchers of culture may avoid an unnecessary mind/body dualism that still seems to permeate much humanistic research. The fact that humans are talented niche-constructors has not lifted them beyond the reach of evolutionary forces (Laland \& Brown 2006). An archaeology that rests on evolutionary foundation demands multi-disciplinary research strategies, and this is something that we regard as an advantage. When the goal is to clarify the selective mechanisms that at a given moment give rise to certain cultural variants/representations and not others, traditional archaeological tools often have to be complemented with extensive knowledge in other sciences such as biology, psychology, economy and so forth. 
Instead of regarding human societies located far from us in time and space as completely different - a view that lately has seemed to be very attractive to Scandinavian prehistorians (Solli 1990) - an emphasis on shared cultural expressions will highlight contacts between peoples regardless of their relative location in time and space. Such studies might, for instance, reveal the cultural ways utilized to adapt to new circumstances that followed natural catastrophes (Diamond 2006; Riede 2008) as well as help us understand what circumstances create the remarkable stability reflected in the material culture of certain time periods. Actually, one of the real challenges of archaeology may very well be to explain cultural stability over long periods of time rather than, as has been the custom, to concentrate on change.

Creating such a link between events and processes in different historical settings is in our view a way of approaching the question of actuality, which is a much debated subject in contemporary archaeology. Why is archaeology relevant and what is the role of archaeology in today's society? The solution, it is sometimes suggested, is to ask people what they want from archaeology, thus popularizing it by making it more accessible and exciting. We think that an evolutionary perspective is of immediate relevance in that it will link the past with the present in a way that a relativistic, exoticizing view of the past does not. In a famous paper the French philosopher Michel Foucault (1992) suggested that the main reason behind the success of the enlightenment was its actuality. The enlightenment was a view of the world that made sense in the Western societies of the I8th and Igth centuries. Actually Foucault proposes that actuality should be the aim of the social sciences. From this point of view, the adoption of evolutionary theory in the social sciences makes perfect sense.

Jan Apel, Department of Archaeology and Osteology, Gotland University College, 62 67 Visby, Sweden

Kim Darmark, Department of Archaeology and Classical Studies, Stockholm University, ro6 91 Stockholm, Sweden 


\section{References}

Apel, J. \& Darmark, K. 2007. Den flathuggna pilspetsens fylogeni. Mellansvenskt stenhantverk ur ett kulturevolutionistiskt perspektiv. In: Stenbäck, N. (Ed.). Stenålder $i$ Uppland. Uppdragsarkeologi och eftertanke. Arkeologi $\mathrm{E}_{4}$ Uppland - Studier Vol. r. Uppsala.

Apel, J. \& Darmark, K. 2009. Cladistics and Flaked Stone Tools - Problems and Possibilities. The Palaeoanthropology Journal. In press.

Bamforth, D. 2002. Evidence and Metaphor in Evolutionary Archaeology. American Antiquity, Vol. 67, No. 3. Pp. 435-452.

Becker, C. J. 1.950. Den grubekeramiske kultur i Danmark. Aarbøger for Nordisk Oldkyndighed og Historie. Copenhagen.

Bentley, R. A. et al. Regular rates of popular change reflect random copying. Evolution and Human Behaviour. Vol. 28. Pp. $5^{1-1} 58$.

Bettinger, R. т99 г. Hunter-Gatherers: archaeological and evolutionary theory. New York. Plenum Press.

Bloch, M. 2005. Essays on Cultural Transmission. Oxford \& New York. Berg.

Boehm, C. 1992. Segmentary 'Warfare' and the Management of Conflict: Comparison of East African Chimpanzees and Patrilineal-Patrilocal Humans. In: Harcourt, A. H. \& De Waal, F. B. M. (Eds.). Coalitions and Alliances in Humans and Other Animals, Oxford. Oxford University Press. Pp. I37-175.

Boyd, R. \& Richerson, P. J. 1985. Culture and the Evolutionary Process. Chicago. University of Chicago Press.

Boyd, R. \& Richerson, P. J. I987. The Evolution of Cultural Markers. Cultural Anthropology, Vol. 2. Pp. 27-38.

Boyd, R. \& Silk, J. B. 2003 . How Humans Evolved (3rd ed). New York. W.W. Norton.

Campbell, D. T. 1974. Evolutionary Epistemology. In: Schilpp, P. A. (Ed). The Philosophy of Karl Popper. La Salle. Open Court.

Cavalli-Sforza, L. 1986. Cultural Evolution. American Zoologist. Vol. 26, No. 3 : Pp. $845^{-855}$.

Cullen, B. S. 2000. Contagious Ideas. On evolution, culture, archaeology, and cultural virus theory. Oxford and Oakville. Oxbow Books.

Darmark, K. In Press. Surface Pressure Flaking in Northern Eurasia at the Mesolithic-Neolithic Transition - A Technological Virus? In: Westerdahl, C. (Ed.). A Circumpolar Reappraisal. BAR. Oxford: Archaeopress.

Diamond, J. 2006. Collapse: how societies choose to fail or survive. London. Penguin.

Eerkens, J.W. \& Lipo, 2007. Cultural Transmission Theory and the Archaeological Record: Providing Context to Understanding Variation and Temporal Changes in Material Culture. Journal of Archaeological Research, Vol. I 5. Pp. 239-274.

Eerkens, J.W. 20oo. Practice Makes Within $5 \%$ of Perfect: Visual Perception, Motor Skills, and Memory in Artifact Variation. Current Antbropology, Vol. 4 I, No.4. Pp. $663-668$.

Engovatova, A.V. 1998. Khronologiya Epokhi Neolita Volga-Okskogo Mezhdurech'ya. Tuerskoy Arkheologicheskiy Sbornik 3. Pp. 238-246.

Fagerström, T. 1994. Efterskrift. In: Darwin, C. Om arternas uppkomst. Stockholm. Natur och kultur.

Forssander,J.-E. T936. Der Ostskandinavische Norden wäbrend der ältesten Metallzeit Europas. Acta Regiae Societatis humaniorum litterarum Lundensis 22. Lund. 
Foucault, M. 1992. Upplysningen, revolutionen och framstegets möjlighet. In: Östling, B. (Ed.). Vad är upplysning? Stockholm. Symposion.

Fracchia, J. \& Lewontin, R. C. 1999. Does Culture Evolve? History and Theory Vol. 48 , Nr. 4. Pp. 52-78.

Gabora, L. 2006. The fate of evolutionary archaeology: survival or extinction? World Archaeology', Vol. 38 , No. 4. Pp. 690-696.

Gopher, A. 1999. Lithic Industries of the Neolithic Period in the Southern Central Levant: A Review. In: Koslowski, S.K. (Ed.). The Eastern Wing of the Fertile Crescent. Late prehistory of Greater Mesopotamian lithic industries. BAR International Series 760 . Pp. I I 6-139.

Gräslund, B. 1.98 I. Människan - en tropisk varelse i arktisk miljö. Tvärsnitt No. 3, т98 ז. Pp. 3-10.

Iriki, A. \& Sakura, O. 2008. The neuroscience of primate intellectual evolution: natural selection and passive and intentional niche construction. Philosophical Transactions of the Royal Society B. 2008. Pp. I-I 3 .

Kol'tsov, L.V. r989. Mezolit SSSR. Moscow. Nauka.

Koslowski, S.K. 1999. The Eastern Wing of the Fertile Crescent. Late prehistory of Greater Mesopotamian lithic industries. BAR International Series 760. Oxford. Archaeopress.

Kristiansen, K. 2004. Genes versus Agents. A discussion of the widening theoretical gap in archaeology. Archaeological Dialogues. Vol. I r. Pp. 77-99.

Kronfeldner, M. E. 2007. Is Cultural Evolution Lamarckian? Biology and Philosophy. Vol. 22. Pp. 493-5I2.

Laland, K. N. \& Brown, G. R. 2006. Niche Construction, Human Behaviour, and the Adaptive-Lag Hypothesis. Evolutionary Anthropology 1 5. Pp. 95-I04.

Leonard, R.D. \& Jones, G.T. 1987. Elements of an Inclusive Evolutionary Model for Archaeology. Journal of Anthropological Archaeology. Vol. 6. Pp. r9y-219.

Lipo, C. P., O'Brien, M. J., Collard, M. \& Shennan, S. J. 2006. Mapping our Ancestors. Phylogenetic Approaches in Anthropology and Prehistory. New Brunswick \& London. Aldine Transaction.

Mace, R., Holden, C. J. \& Shennan, S. (Eds.). 2005. The Evolution of Cultural Diversity. A Phylogenetic Approach. London. University College London Institute of Archaeology Publications.

Malmström, H., Vila, C., Gilbert, M. T. P., Storå, J., Willerslev, E., Holmlund, G. \& Götherström, A. 2008. Barking up the wrong tree: Modern northern European dogs fail to explain their origin. BMC Evolutionary Biology. Vol. 8: $7 \mathrm{r}$.

Mesoudi, A. 2008. Foresight in cultural evolution. Biology and Philosophy, 23. Pp. $243-255$.

Mesoudi, A., Whiten, A. \& Laland, K. N. 2006. Towards a unified science of cultural evolution. Behavioural and Brain Sciences Vol. 29, Pp. 329-383.

Oshibkina, S.V. r996. Neolit Severnoy Eurazii. Moscow. Nauka.

Persson, P. r.999. Arkeologi och evolutionism. In: Gustavsson, A. \& Karlsson, H. (Eds.), Glyfer och arkeologiska rum - en vänbok till Jarl Nordbladh. Göteborg. Pp. 667-678.

Riede, F. 2005 . Darwin vs. Bourdieu - Celebrity Deathmatch or Processual Myth? A Prolegomenon for the Reconciliation of Agentive-Interpretative and Ecological-Evolutionary Archaeology. In: Cobb, H. L., Coward, F., Grimshaw, L. \& Price, S. (Eds.), Investigating Prehistoric Hunter-Gatherer Identities: Case Studies from Palacolithic and Mesolithic. BAR International Series 1411 . Oxford. Archaeopress. 
Riede, F. 2006. The Scandinavian Connection: The Roots of Darwinian Archaeology in I9th-Century Scandinavian Archaeology. Bulletin of the History of Ar. chaeology. Vol. i 6 , No. r. Pp. 4-I 8.

Riede, F. 2008. The Laacher See-eruption (12,920 BP) and material culture change at the end of the Allered in Northern Europe. Journal of Archaeological Science. Vol. 35, No. 3. Pp. 59 I-599.

Rodseth, L., Wrangham, R. W., Harrigan, A. M. and Smuts, B. B. I991. The Human Community as a Primate Society. Current Anthropology. Vol. 32. Pp. 22 I-254.

Runciman, W. G. 2005. Culture Does Evolve. History and Theory. Vol. 44. Pp. I-I3.

Savolainen, P., Zhang, Y., Luo, J., Lundeberg, J. \& Leiner, T. 2002. Genetic Evidence for an East Asian Origin of Domestic Dogs. Science. Vol. 298. Pp. I610-161 3.

Shanks, M. \& Tilley, C. 1987. Social Theory and Archaeology. London. Polity Press.

Shennan, S. 2000. Population, Culture History, and the Dynamics of Culture Change. Current Anthropology. Vol. 4 I. Nr.5. Pp. 8 I I I-835.

Shennan, S. 2002. Genes, Memes and Human History. Darwinian Archaeology and Cultural Evolution. London. Thames \& Hudson.

Shennan, S. 2009. Pattern and Process in Cultural Evolution. Berkeley. University of California Press.

Solli, B. 1990. Forntiden er et annet sted. Om arkeologi och kulturminnevern, røtter og fotter. Norsk antropologisk tidskrift.

Stout, D. 2002. Skill and Cognition in Stone Tool Production. An ethnographic case study from Irian Jaya. Current Anthropology. Vol. 43, No. 5. Pp. $693-722$.

Tehrani, J. J. \& Riede, F. 2008. The role of pedagogy in the transmission and maintenance of cultural traditions. World Archaeology. Vol. 40, No.3. Pp. 3 I6-33 I.

Tiffagom, M. 2006. De la pierre à l'homme. Essai sur une Paléoanthropologie solutréenne. ERAUL 11 3. Liège. Eraul.

Tooby, J. \& Cosmides, L. r997. Evolutionary Psychology: A Primer. www.psych.ucsb.edu/research/cep/primer.html

Vang Petersen, P. 1999. Flint fra Danmarks Oldtid. Copenhagen. Høst \& Søn.

Wenke, R. J. 1989. Comments on Archaeology into the r 990 os. Norwegian Archaeological Review. Vol. 22, No.1. Pp. $3 \mathrm{I}-33$.

White, L. A. 1959. The Evolution of Culture. The Development of Civilization to the Fall of Rome. New York. McGraw-Hill.

Workman, L. \& Reader, W. 2004. Evolutionary Psychology. An Introduction. Cambridge. Cambridge University Press. 